\title{
Mutation of tumor suppressor gene p53 in hepatocellular carcinomas from Korea
}

\author{
Young-Min Park ${ }^{1,2,6}$, Young-Do Yoo ${ }^{3}$, \\ Soon-Young Paik ${ }^{4}$, Boo-Sung Kim ${ }^{2}$ and \\ Edward Tabor ${ }^{1,5}$ \\ 1 National Cancer Institute, National Institutes of Health, \\ Bethesda, Maryland, U.S.A. \\ 2 Department of Internal Medicine, Kangnam St. Mary's Hospital, \\ Catholic University Medical School, Seoul, Korea \\ 3 Laboratory of Experimental Therapeutics, \\ Korean Cancer Center Hospital, Seoul, Korea \\ 4 Department of Microbiology, Catholic University Medical School, \\ Seoul, Korea \\ 5 Food and Drug Administration, Bethesda, Maryland, U.S.A. \\ 6 Corresponding author \\ Accepted 21 November 1996
}

Abbreviations: $\mathrm{HBsAg}$, hepatitis B surface antigen; $\mathrm{HBeAg}$, hepatitis $\mathrm{B}$ e antigen; $\mathrm{HCV}$, hepatitis $C$ virus; $S S C P$, single strand conformation polymorphism

\begin{abstract}
Mutation of the p53 gene in hepatocellular carcinoma has been recognized as one of the most important genetic alterations to occur during hepatocarcinogenesis. This study was performed to analyze the frequency and nature of p53 mutations in advanced hepatocellular carcinomas from Korea. Tissue samples were obtained by laparoscopic biopsy from 35 patients; adjacent nontumorous liver tissue was also obtained from 24 of them. Mutations of the p53 gene were identified in $11 / 35(31 \%)$ of hepatocellular carcinomas. These included 7 missense mutations and 4 deletion mutations. Only one mutation was detected at codon 249, a "hot spot" at which mutations have been found frequently in hepatocellular carcinomas from some geographic areas; however, this was an A-to-T transversion at the first nucleotide, thus differing from commonly reported G-to-T transversion at the third nucleotide of codon 249 in hepatocellular carcinomas. Patients whose serum alkaline phosphatase levels were higher than the mean value were more likely to have p53 mutations, compared to patients whose alkaline phosphatase levels were lower than the mean value [55\% (6/11) vs. $21 \%(5 / 24)](p<0.05)$. Thus, p53 mutations are found in many hepatocellular
\end{abstract}

carcinomas in Korea. However, mutations commonly thought to be due to aflatoxin $B_{1}$ (G-to-T transversion at codon 249) were not found, suggesting that aflatoxin- $B_{1}$ does not play an important role in the etiology of hepatocellular carcinoma in Korea.

Keywords: reverse transcription-polymerase chain reaction, polymerase chain reaction-single strand conformation polymorphism, p53, tumor suppressor gene, hepatocellular carcinoma

\section{Introduction}

Hepatocellular carcinoma is one of the most common cancers in the world. Chronic infection with hepatitis B virus and hepatitis $C$ virus are important etiologic factors for the development of hepatocellular carcinoma, but it is also possible that other factors such as chemical carcinogens may contribute to carcinogenesis. The tumor suppressor gene p53 has been found to be commonly mutated in various human tumors including hepatocellular carcinoma (Nigro et al., 1989; Levine et al., 1991; Hollstein et al., 1991; Harris and Hollstein, 1993). A mutation at p53 codon 249 with a G-to-T transversion at the third nucleotide has been found frequently in hepatocellular carcinomas from southern Africa and Qidong, China, areas in which dietary aflatoxin $B_{1}$ may play an important role in the etiology of hepatocellular carcinoma (Hsu et al., 1991; Bressac et al., 1991; Ozturk et al., 1991). However, hepatocellular carcinomas from geographic areas where aflatoxin is uncommon in the diet do not have such a mutational "hot spot" for p53 (Ozturk et al., 1991; Unsal et al., 1994). These observations indicate that the molecular mechanisms of p53 gene damage or dysfunction in hepatocarcinogenesis may be heterogeneous. In the present study, exons 3 to 9 of the p53 gene were investigated to determine the frequency, nature, and significance of mutations in these genes in advanced hepatocellular carcinomas from Korea.

\section{Materials and Methods}

\section{Liver tissues}

Hepatocellular carcinoma tissues were collected from 35 patients with advanced hepatocellular carcinoma (TNM stage III or IV), who were seen at the Department of Internal Medicine, St. Mary's Hospital, Catholic 
University Medical College, Seoul, Korea, between 1990 and 1993. Laparoscopic biopsy was performed on all 35 patients; hepatocellular carcinoma was available from 35 and adjacent nontumorous liver was available from 24.

Patients ages were 18 to 74 years (median, 52 years); 31 patients were male, 4 patients were female. Twenty-six patients $(74 \%)$ had hepatitis B surface antigen ( $\mathrm{HBsAg})$ in serum, including 13 hepatitis $B$ e antigen ( $\mathrm{HBeAg})$-positive and $13 \mathrm{HBeAg}$-negative patients. Four patients $(11 \%)$ had antibody to hepatitis $\mathrm{C}$ virus (anti-HCV) and no detectable HBsAg. One other patient was positive for both $\mathrm{HBsAg}$ and anti-HCV and 4 patients were negative for both. As determined by visual inspection at laparoscopy, 23 patients (66\%) had cirrhosis, 8 patients $(23 \%)$ had chronic active hepatitis and 4 patients (11\%) had normal liver surface. As determined by computerized tomography, 6 patients had hepatocellular carcinoma with TNM stage III and 29 patients had TNM stage IVa. Histologic grade based on the Edmondson-Steiner classification was available for 33 tumors; 3 were grade I (9\%), 15 were grade II $(46 \%)$, and 15 were grade III (46\%). Tissues obtained at laparoscopy were snap-frozen and stored in liquid nitrogen until use.

\section{Serological markers}

HBsAg, antibody to HBsAg (anti-HBs), HBeAg, antibody to $\mathrm{HBeAg}$ (anti-HBe), and total antibody to hepatitis core antigen (anti-HBc) were assayed using commercially available radioimmunoassay kits (Abbott Laboratories, Chicago, IL). Anti-HCV was assayed with a second generation enzyme immunoassay kit (Abbott Laboratories).

\section{Extraction of total RNA and reverse transcription}

Total RNA was prepared from hepatocellular carcinoma and liver tissue by the acid guanidinium thiocyanatephenol-chloroform method (Chomçzinski and Sacchi, 1987). Each RNA sample (2 $\mu \mathrm{g})$ was reversetranscribed with $10 \mathrm{pmol}$ of an antisense primer (5'CTGACGCACACCTATTGCAA) derived from the exon 11 of the p53 gene, and 200 units of Moloney murine leukemia virus reverse transcriptase (GIBCO BRL, Gaithersburg, MD) at $37^{\circ} \mathrm{C}$ for $60 \mathrm{~min}$ in a total reaction volume of $10 \mu \mathrm{l}$.

\section{PCR-single strand conformation polymorphism (PCR- SSCP)}

The sense and antisense primers used for amplifying exons 3 to 9 were made with published primer sequences (Nagai et al., 1991) (Figure 1). A DNA segment extending from the distal part of exon 1 to the proximal part of exon 11 was amplified in a $50 \mu \mathrm{l}$ reaction volume containing $10 \mathrm{mM}$ Tris- $\mathrm{HCl}(\mathrm{pH} 8.3), 50$ $\mathrm{mM} \mathrm{KCl}, 1.5 \mathrm{mM} \mathrm{MgCl}_{2}, 0.01 \%$ gelatin, $200 \mu \mathrm{M}$ each of the four deoxynucleoside triphosphates (dATP, dCTP, dGTP, and dTTP), $1 \mu \mathrm{M}$ each of outer sense primer (5'TCCACGACGGTGACACGCTT) and outer antisense

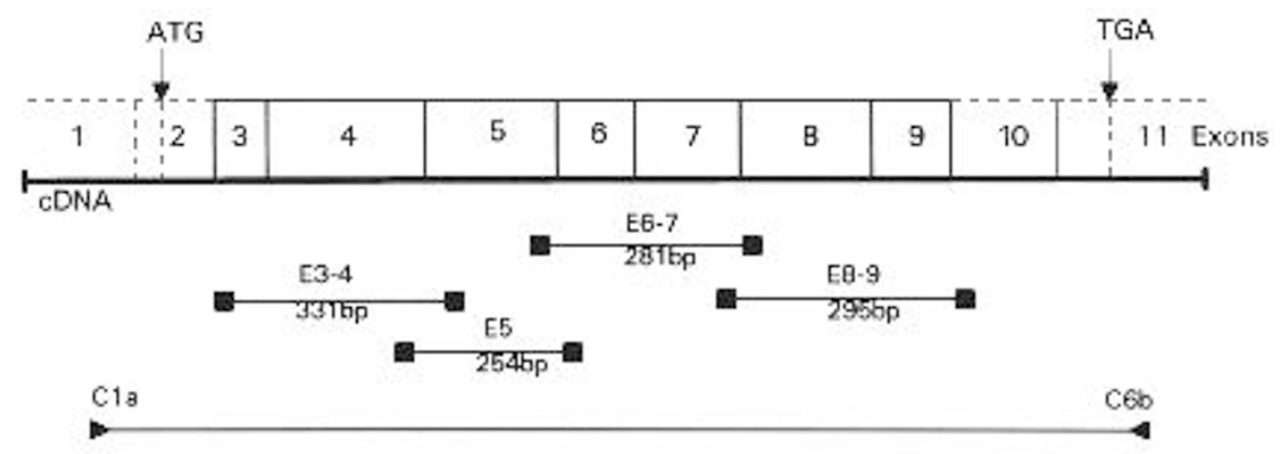

$\begin{array}{lll}\text { E3-4a } & \text { sense } & \text { 5'-ACTTCCTGAAAACAACGTTC } \\ \text { E3-4b } & \text { anti-sense } & \text { 5'-GCAAAACATCTTGTTGAGGG } \\ \text { E5a } & \text { sense } & \text { 5'-TTGCATTCTGGGACAGCCAA } \\ \text { E5b } & \text { anti-sense } & \text { 5'-CCTTCCACTCGGATAAGATG } \\ \text { E6-7a } & \text { sense } & \text { 5'-ACCATGAGCGCTGCTCAGAT } \\ \text { E6-7b } & \text { anti-sense } & \text { 5'-TCAAAGCTGTTCCGTCCCAG } \\ \text { E8-9a } & \text { sense } & \text { 5'-CACCATCATCACACTGGAAG } \\ \text { E8-9b } & \text { anti-sense } & \text { 5'-GAGTTCCAAGGCCTCATTCA } \\ \text { C1a } & \text { sense } & \text { 5'-TCCACGACGGTGACACGCTT } \\ \text { C6b } & \text { anti-sense } & \text { 5'-CTGACGCACACCTATTGCAA }\end{array}$

Figure 1. A strategy of reverse transcription-PCR and single-strand conformation polymorphism analysis. Reverse transcription reaction was performed with the $\mathrm{C} 6 \mathrm{~b}$ primer. The first stage of PCR was performed with the $\mathrm{C} 1 \mathrm{a}$ and $\mathrm{C} 1 \mathrm{~b}$ primers. The second stage of PCR was performed with the radiolabelled inner primers: the primer sets cover exons 3 and 4 (E3-4), exon 5 (E5), exons 6 and 7 (E6-7), and exons 8 and 9 (E8-9), respectively. 
primer (5'-CTGACGCACACCTATTGCAA), 0.5 units of Taq polymerase, and $10 \mu$ of cDNA. PCR was processed for 15 cycles (denaturation at $95^{\circ} \mathrm{C}$ for $1 \mathrm{~min}$, primer annealing at $55^{\circ} \mathrm{C}$ for $1 \mathrm{~min}$, and polymerization at $72^{\circ} \mathrm{C}$ for $2 \mathrm{~min}$ ).

For the SSCP, PCR was carried out with the SSCP primer sets (Figure 1), of which the 5 '-terminus was labeled with $\left[\gamma^{-}{ }^{33}\right.$ P]ATP (Amersham, Arlington Heights, IL) using T4 polynucleotide kinase (Promega, Madison, $\mathrm{WI}$ ). The reaction volume of the PCR was $5 \mu \mathrm{I}$, containing $125 \mu \mathrm{M}$ each of the dNTPs, $0.1 \mu \mathrm{M}$ each of radiolabeled sense and antisense SSCP primers, 0.5 units of Taq polymerase, and $1 \mu \mathrm{l}$ of the first PCR products as described above. PCR was performed for 30 cycles (denaturation at $95^{\circ} \mathrm{C}$ for $30 \mathrm{sec}$, primer annealing at $55^{\circ} \mathrm{C}$ for $30 \mathrm{sec}$, and polymerization at $72^{\circ} \mathrm{C}$ for $1 \mathrm{~min}$ ). Each PCR product was diluted 10 fold with distilled water and $1 \mu$ leach of the PCR diluents was mixed with $3 \mu \mathrm{l}$ of gel loading dye containing $95 \%$ formamide, $20 \mathrm{mM}$ EDTA, 0.05\% xylene cyanol FF, and $0.05 \%$ bromophenol blue. The sample heated at $95^{\circ} \mathrm{C}$ for $3 \mathrm{~min}$, immediately cooled on ice, and loaded on $5 \%$ polyacrylamide gel (acrylamide: N,N-methylene-bisacrylamide $=49: 1$ ) with or without $10 \%$ glycerol. The electrophoresis buffer contained $45 \mathrm{mM}$ Tris-borate $(\mathrm{pH}$ 8.3) and $1 \mathrm{mM}$ EDTA. The gel $(40 \mathrm{~cm} \times 40 \mathrm{~cm} \times 0.04$ $\mathrm{cm}$ in size) was run at 10 watts overnight with the temperature maintained at $23-24^{\circ} \mathrm{C}$. In some cases, an additional minigel $(10 \mathrm{~cm} \times 10 \mathrm{~cm} \times 0.7 \mathrm{~cm}$ in size) with $10 \%$ polyacrylamide gel (49:1) was run at $200-300$ volts for $3 \mathrm{~h}$ with the temperature maintained at $10^{\circ} \mathrm{C}$ with cold-water circulation. After electrophoresis, the gels were exposed to $x$-ray film (XOMAT-AR5) with an intensifying screen at $-70^{\circ} \mathrm{C}$ overnight.

\section{DNA Sequencing}

Sequencing was performed according to the Sanger dideoxy chain termination method using a direct sequencing kit ("fmol", Promega). Each SSCP primer, which was end-labeled with $\left[\gamma^{-33}\right.$ P]ATP (Amersham) as described above, was used as a sequencing primer. The first PCR products of the samples with abnormal SSCP bands were used as sequencing templates. Sequencing products were electrophoresed with $6 \%$ polyacrylamide/7 M urea gel, dried at $80^{\circ} \mathrm{C}$ for $1 \mathrm{~h}$ with a gel drier, and autoradiographed at $-70^{\circ} \mathrm{C}$ overnight.

\section{Statistical Analysis}

Data was analyzed using unpaired $t$-test, chi-square test, and Mann-Whitney U test.

\section{Results}

Abnormalities of the p53 gene were identified in 11 of 35 hepatocellular carcinomas $(31 \%)$, including 7 missense mutations in exons $5,6,7$, and 8,3 short deletions (15-, 18- and 63-bp each) in parts of exons 4 and 8 , and 1 large deletion including exons 2 to 6 (Table 1, 2).

Of the 7 missense mutations, 4 were transitions and 3 were transversions. One of the missense mutations was in codon 249 with an A-to-T transversion (AGG to IGG; Arg to Trp). The only G-to-T transversion was in codon 176 (TGG to TIC, Cys to Phe) (Table 1 and Figure 2).

Seven of the 26 hepatocellular carcinomas (27\%) from patients with serum $\mathrm{HBsAg}$ and no detectable anti-HCV had p53 mutations. Mutations or deletions

Table 1. Mutations of the p53 gene in hepatocellular carcinoma

\begin{tabular}{|c|c|c|c|c|c|c|c|}
\hline Case & $\mathrm{HBsAg}$ & Anti-HCV & Exon & Codon & Nucle & Change & Amino Acid change \\
\hline K6 & + & - & 5 & 179 & Transversion & $\underline{\text { CAT }} \rightarrow$ GAT & $\mathrm{His} \rightarrow$ Asp \\
\hline K22 & + & - & 6 & 215 & Transition & $\underline{A G T} \rightarrow \underline{G G T}$ & Ser $\rightarrow$ Gly \\
\hline K23 & + & - & 6 & 220 & Transition & TㅁT $\rightarrow$ T $\underline{\text { GT }}$ & Tyr $\rightarrow$ Cys \\
\hline K26 & + & - & 7 & 249 & Transversion & $\underline{A G G} \rightarrow \underline{I G G}$ & $\operatorname{Arg} \rightarrow \operatorname{Trp}$ \\
\hline K5 & + & - & 8 & 278 & Transition & $\underline{\mathrm{CCT}} \rightarrow \underline{\mathrm{TCT}}$ & Pro $\rightarrow$ Ser \\
\hline K16 & + & - & 8 & $277-281$ & 15-base deleti & ithout frameshift ${ }^{\mathrm{a}}$ & \\
\hline K15 & + & - & $2-6$ & & Deletion of $5 \epsilon$ & ( $(2$ to 6$)$ & \\
\hline K32 & - & + & 7 & 258 & Transition & $\underline{G A A} \rightarrow \underline{G G A}$ & Glu $\rightarrow$ Gly \\
\hline K35 & + & + & 4 & $44-50$ & 18-base deleti & ithout frameshift ${ }^{b}$ & \\
\hline $\mathrm{K} 37^{\mathrm{d}}$ & - & - & 4 & $105-126$ & 63-base deleti & ithout frameshift ${ }^{\mathrm{c}}$ & \\
\hline K40 & - & - & 5 & 176 & Transversion & $\mathrm{TG} C \rightarrow \mathrm{TIC}$ & Cys $\rightarrow$ Phe \\
\hline
\end{tabular}

\footnotetext{
a GCC TGT CCT GGG AGA

${ }^{\mathrm{b}} \mathrm{G}$ ATG CTG TCC CCG GAC GA

${ }^{\circ}$ G GGC AGC TAC GGT TTC CGT CTG GGC TTC TTG CAT TCT GGG ACA GCC AAG TCT GTG ACT TGC AC

${ }^{d}$ HBV-DNA-positive by PCR
} 
Table 2. Mutation patterns of the p53 gene and hepatitis virus infection

\begin{tabular}{|c|c|c|c|c|c|}
\hline \multirow[b]{2}{*}{ Mutations } & \multirow[b]{2}{*}{$\begin{array}{l}\text { No. of Cases } \\
\qquad(n=35)\end{array}$} & \multicolumn{4}{|c|}{ Hepatitis Virus Markers } \\
\hline & & $\begin{array}{c}\mathrm{HBsAg}(+) / \\
\text { anti-HCV }(-) \\
(n=26)\end{array}$ & $\begin{array}{l}\mathrm{HBsAg}(-) / \\
\text { anti-HCV (+) } \\
(\mathrm{n}=4)\end{array}$ & $\begin{array}{c}\mathrm{HBsAg}(+) / \\
\text { anti-HCV }(+) \\
(n=1)\end{array}$ & $\begin{array}{l}\operatorname{HBsAg}(-) / \\
\text { anti-HCV (-) } \\
(n=4)\end{array}$ \\
\hline \multicolumn{6}{|l|}{ Transition } \\
\hline A to $G$ & $3(9 \%)$ & 2 & 1 & 0 & 0 \\
\hline $\mathrm{C}$ to $\mathrm{T}$ & $1(3 \%)$ & 1 & 0 & 0 & 0 \\
\hline \multicolumn{6}{|l|}{ Transversion } \\
\hline $\mathrm{C}$ to $\mathrm{G}$ & $1(3 \%)$ & 1 & 0 & 0 & 0 \\
\hline $\mathrm{A}$ to $\mathrm{T}$ & $1(3 \%)$ & 1 & 0 & 0 & 0 \\
\hline $\mathrm{G}$ to $\mathrm{T}$ & $1(3 \%)$ & 0 & 0 & 0 & 1 \\
\hline \multicolumn{6}{|l|}{ Deletion } \\
\hline In one exon & $3(9 \%)$ & 1 & 0 & 1 & $1^{b}$ \\
\hline Multiple exons & $1(3 \%)^{a}$ & 1 & 0 & 0 & 0 \\
\hline Total Number & $11(31 \%)$ & $7(27 \%)$ & $1(25 \%)$ & $1(100 \%)$ & $2(50 \%)$ \\
\hline
\end{tabular}

${ }^{a}$ Deletion of 5 exons ( 2 to 6 )

${ }^{\mathrm{b}}$ HBV-DNA-positive by PCR

A Exon $4-$ Codon 72

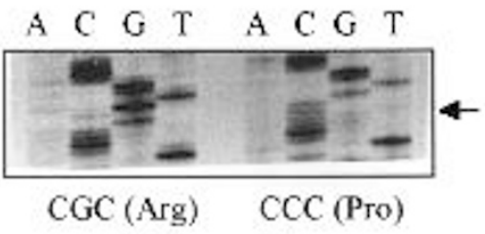

Polymorphism

D Exon $6-$ Codon 220

$\mathrm{A} C \mathrm{G}$ T A C G T

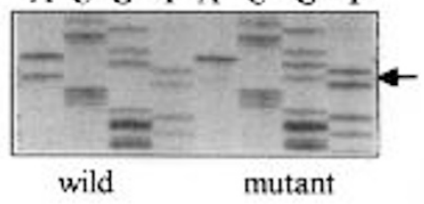

TAT to TGT (Tyr to Cys)

G Exon 8 - Codon 278

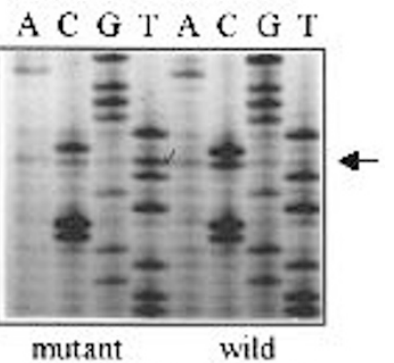

CCT to TCT (Pro to Ser)
B Finn $\subseteq-$ Coxton 179

$A C G T A C T$

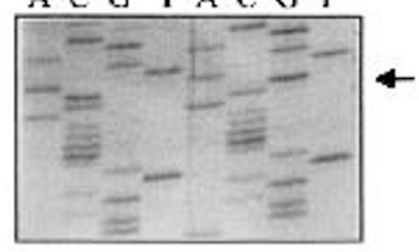

wild mutant

CAT to GaT (His to Asp)

E Exon 7 - Codon 249

A $C \mathrm{G}$ T $\triangle \mathrm{C}$ G T

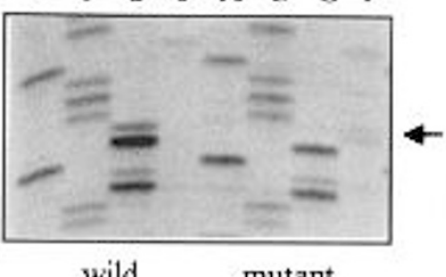

AGG to AGT (Arg to Ser)

H Exor 7 -Codon 249

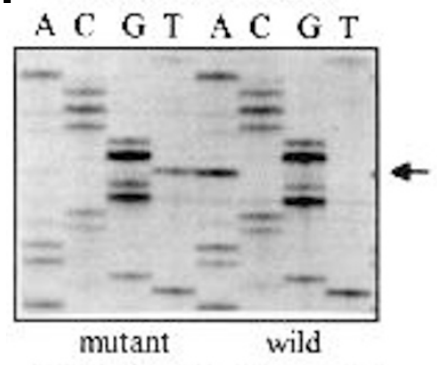

AGG to TGG (Arg to Trp)
C Exon $6 \cdot$ Codon 215

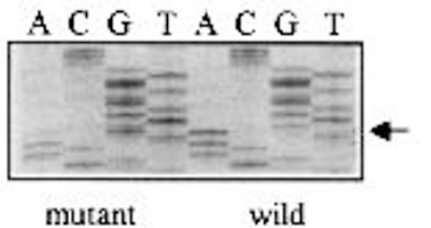

AGT to GGT (Ser to Gly)

F Exon 7 - Codon 258

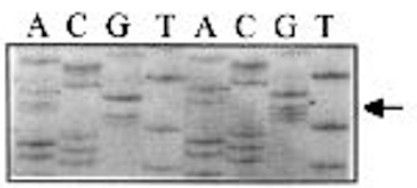

wild mutant

GAA to GGA (Glu to Gly)

Figure 2. Sequencing of p53 exons 3-9 in hepatocellular carcinomas from 35 patients was performed by the dsDNA cycle sequencing method. A polymorphism at codon 72 , as shown in panel $2 \mathrm{~A}$, was found in several cases. Seven missense mutations were identified in each of 7 patients; these were located throughout exons 5 to 8 , as shown in panels 2B-2H. See also Table 1. 
were found in one of 4 hepatocellular carcinomas from patients with anti-HCV and no detectable $\mathrm{HBsAg}$, one of one with both HBsAg and anti-HCV, and two of four negative for both viral markers (Table 2).

None of the 24 samples of non-tumorous liver tissues adjacent to hepatocellular carcinomas had p53 mutations. Tumor size, portal vein thrombosis, and differentiation grade of the hepatocellular carcinomas did not show a significant relationship with p53 mutations. Among the laboratory parameters, only the serum alkaline phosphatase level was correlated with the p53 mutations; p53 mutations were found more often in those patients with serum alkaline phosphatase level higher than the mean value, compared to patients with alkaline phosphatase level lower than the mean value $(55 \%$ [6/11] vs $21 \%$ [5/24], $p=0.046$ ) (Table 3,4 and 5).

\section{Discussion}

Mutation in the p53 tumor suppressor gene may be an important event in the transformation of hepatocytes (Bressac et al., 1990). p53 mutations are common in hepatocellular carcinomas throughout Asia. In Chinese patients, including those from Hong Kong and Taiwan, where hepatitis B virus is closely associated with hepatocellular carcinoma, p53 mutations have been

Table 3. p53 mutations and characteristics of the hepatitis $B$ virus infection

\begin{tabular}{llcc}
\hline Characteristics of the HBV infection & No. analyzed & p53 mutations \\
\hline $\mathrm{HBeAg}^{\mathrm{a}}$ & Positive & 13 & $4(31 \%)$ \\
\multirow{3}{*}{ HBV-DNA $^{\mathrm{b}}$} & Negative & 13 & $3(23 \%)$ \\
\multirow{3}{*}{ Precore Codon 28c } & Positive & 25 & $8(32 \%)$ \\
& Negative & 9 & $3(33 \%)$ \\
& Wild-type & 5 & $1(20 \%)$ \\
& Mutant & 7 & $1(14 \%)$ \\
\hline
\end{tabular}

${ }^{a}$ All cases are HBsAg-positive.

${ }^{\mathrm{b}} \mathrm{HBV}$-DNA detectable in serum by PCR.

${ }^{\mathrm{c}}$ Sequence variations in precore codon 28 of HBV genome: wild-type, TGG (Trp); mutant, TAG (stop) mutation; mixed, coexistance of both wild-type and mutant HBV. For each parameter, differences in prevalence of p53 mutations between the groups were not statistically significant.

Table 4. Characteristics of hepatocellular carcinomas and p53 mutation

\begin{tabular}{|c|c|c|c|}
\hline \multirow{2}{*}{\multicolumn{2}{|c|}{ HCC Characteristics }} & \multicolumn{2}{|c|}{ Number of Cases } \\
\hline & & Analyzed & p53 Mutations \\
\hline \multirow[t]{2}{*}{ TNM Stage } & III & 6 & $2(33 \%)$ \\
\hline & IVa & 29 & $9(31 \%)$ \\
\hline \multirow[t]{2}{*}{ Sizea } & $<10 \mathrm{~cm}$ & 12 & $3(25 \%)$ \\
\hline & $>9 \mathrm{~cm}$ & 19 & $7(37 \%)$ \\
\hline \multirow{2}{*}{ Portal Vein Thrombosis } & Negative & 10 & $2(20 \%)$ \\
\hline & Positive & 20 & $8(40 \%)$ \\
\hline \multirow{2}{*}{ Configuration of Tumorb } & Massive & 7 & $3(43 \%)$ \\
\hline & Multiple & 19 & $8(42 \%)$ \\
\hline \multirow[t]{2}{*}{ Differentiation } & Well to Moderate & ately 18 & $4(22 \%)$ \\
\hline & Poorly & 15 & $6(40 \%)$ \\
\hline
\end{tabular}

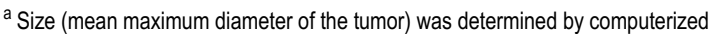
tomogram.

${ }^{b}$ Configuration of tumor as determined by computerized tomogram: Massive, single large mass $(>5 \mathrm{~cm})$ with or without visible daughter nodules; multiple, multi-focal masses in single lobe or both lobes. For each parameter, the differences in prevalence of p53 mutations between the groups were not statistically significant.
Table 5. Mutations of the p53 gene and age, laparoscopic findings, alpha-fetoprotein (AFP) and alkaline phosphatase (AP)

\begin{tabular}{lccc}
\hline & & \multicolumn{2}{c}{ Number of Cases } \\
\cline { 3 - 4 } & & Analyzed & p53 Mutations \\
\hline \multirow{2}{*}{ Age (Mean) } & $<51$ years & 15 & $7(47 \%)$ \\
& $>51$ years & 20 & $4(20 \%)$ \\
Laparoscopic findings & cirrhosis & 23 & $5(22 \%)$ \\
& hepatitis & 8 & $3(38 \%)$ \\
& non-specific & 4 & $3(75 \%)$ \\
AFP (ng/ml) (Mean) & $<793$ & 12 & $3(25 \%)$ \\
& $>793$ & 19 & $7(37 \%)$ \\
AP (IU/L) (Mean) & & & \\
& $<471$ & 24 & $5(21 \%)$ \\
& $>471$ & 11 & $6(55 \%)$ \\
\hline
\end{tabular}

${ }^{a} p=0.046$. 
reported in 23-33\% (Sheu et al., 1992; Hsu et al., 1993; Hsu et al., 1994; Ng et al., 1994). In Japan, where hepatitis $C$ virus is the predominant virus associated with hepatocellular carcinoma, p53 mutations were reported in 30-65\% (Murakami et al., 1991; Oda et al., 1992; Nishida et al., 1993; Nose et al., 1993; Teramoto et al., 1994). In the present study, p53 mutation was identified in $31 \%(11 / 35)$ of advanced hepatocellular carcinomas from Korea, a country where hepatitis $B$ virus is the virus most commonly associated with hepatocellular carcinoma.

In general, compared to other tumor suppressor genes such as the Rb and APC genes, missense mutations are much more common in the p53 gene; usually comprising more than $90 \%$ of all the p53 mutations (Harris, 1993), and transversions are most common in hepatocellular carcinomas in large part due to G-to-T transversion at codon 249 (Harris and Hollstein, 1993). Among hepatocellular carcinomas from Taiwan, $71 \%$ of the alterations in the p53 gene were due to missense mutations (Hsu et al., 1994). In the present study, $64 \%$ were missense mutations, in which transversions were not dominant, and $36 \%$ were deletion mutations.

Aflatoxin $B_{1}$ is strongly associated with a G-to-T transversion in the third nucleotide position of codon 249 of the p53 gene (Hsu et al., 1991). Mutations at this hot spot were found in $58 \%$ in hepatocellular carcinoma patients from China (Scorsone et al., 1992; Li et al., 1993; Fujimoto et al., 1994), but in $10 \%$ of hepatocellular carcinoma patients from Taiwan (Sheu et al., 1992; Hsu et al., 1994) and in few (Oda et al., 1992) or none of Japanese hepatocellular carcinomas (Murakami et al., 1991; Nishida et al., 1993; Nose et al., 1993; Teramoto et al., 1994). In the present study, none of the cases had a $G$ to $T$ transversion at p53 codon 249 , indicating that aflatoxin $B_{1}$ may not play an important role in hepatocarcinogenesis of Korean hepatocellular carcinomas.

This G-to-T transversion in p53 codon 249 was also found in the nonmalignant liver from some patients with hepatocellular carcinoma from Qidong (Aguilar et al., 1994). However, none of the adjacent nontumorous liver tissues of Korean patients with hepatocellular carcinoma had p53 mutations.

In hepatitis virus-associated hepatocellular carcinomas, it has been suggested that the occurrence of the genetic aberrations in the p53 gene may be a late event in hepatocarcinogenesis (Teramoto et al., 1994). Additionally, it was also suggested that the p53 mutations in hepatocellular carcinoma may be correlated with the higher serum alpha-fetoprotein level, the presence of thrombosis of the main portal vein, or poorly differentiated hepatocellular carcinoma (Hsu et al., 1994). However, the present study did not show statistically significant differences in these factors. These findings were similar to those reported by other researcher (Hong et al., 1995) The only significant factor associated with the occurrence of p53 mutations in hepatocellular carcinomas was a higher serum alkaline phosphatase level.

\section{References}

Aguilar, F., Harris, C. C., Sun, T., Hollstein, M. and Cerutti, P. (1994) Geographic variation of $p 53$ mutational profile in nonmalignant human liver. Science 264: $1317-$ 1319

Bressac, B., Galvin, K. M., Liang, T. J., Isselbacher, K. J., Wands, J. R. and Ozturk, M. (1990) Abnormal structure and expression of p53 gene in human hepatocellular carcinoma. Proc. Natl. Acad. Sci. U.S.A. 87: 1973-1977

Bressac, B., Kew, M., Wands, J. and Ozturk, M. (1991) Selective G to T mutations of p53 gene in hepatocellular carcinoma from southern Africa. Nature 350:429-431

Chomçzynski, P. and Sacchi, N. (1987) Single-step method of RNA isolation by acid guanidinium thiocyanate-phenol-chloroform extraction. Anal. Biochem. 162: 156-159

Fujimoto, Y., Hampton, L. L., Wirth, P. J., Wang, N. J., Xie, J. P. and Thorgeirsson, S. S. (1994) Alterations of tumor suppressor genes and allelic losses in human hepatocellular carcinomas in China. Cancer Res. 54: 281-285

Harris, C. C. (1993) p53: at the crossroads of molecular carcinogenesis and risk assessment. Science 262: 1980-1981

Harris, C. C. and Hollstein, M. (1993) Clinical implications of the p53 tumor-suppressor gene. N. Engl. J. Med. 329: 1318-1327

Hollstein, M., Sidransky, D., Vogelstein, B. and Harris, C. C. (1991) p53 mutations in human cancers. Science 253: 49-53

Hong, G.-T., Choi, D.-W., Lee, J.-I., Paik, N.-S., Moon, N.-M. and Lee, S.-S. (1995) Prognostic significances of $\mathrm{p} 53$ protein and other prognostic factors in hepatocellular carcinoma patients. Korean.J. Cancer 27: 916-923

Hsu, I. C., Metcalf, R. A., Sun, T., Welsh, J. A., Wang, H. I. and Harris, C. C. (1991) Mutational hotspot in the p53 gene in human hepatocellular carcinomas. Nature 350 : 427-428

Hsu, H.-C., Tseng, H.-J., Lai, P.-L., Lee, P.-H. and Peng, S.-Y. (1993) Expression of p53 gene in 184 unifocal hepatocellular carcinomas: association with tumor growth and invasiveness. Cancer Res. 53: 4691-4694

Hsu, H.-C., Peng, S.-Y., Lai, P.-L., Chu, J.-S. and Lee, P.-H. (1994) Mutations of p53 gene in hepatocellular carcinoma $(\mathrm{HCC})$ correlate with tumor progression and patient prognosis: a study of 138 patients with unifocal HCC. Int. J. Oncol. 4: 1341-1347

Levine, A. J., Momand, J. and Finlay, C. A. (1991) The p53 tumour suppressor gene. Nature 351: 453-456

Li, D., Cao, Y., He, L., Wang, N. J. and Gu, J.-R. (1993) Aberrations of p53 gene in human hepatocellular carcinoma from China. Carcinogenesis 14: 169-173

Murakami, Y., Hayashi, K., Hirohashi, S. and Sekiya, T. (1991) Aberra-tions of the tumor suppressor p53 and retinoblastoma genes in human hepatocellular carcinomas. Cancer Res. 51: 5520-5525

Nagai, H., Kinoshita, T., Imamura, J., Murakami, Y., Hayashi, K., Mukai, K., Ikeda, S., Tobinai, K., Saito, H., Shimoyama, M. and Shimotohno, K. (1991) Genetic alteration of p53 in some patients with adult T-cell leukemia. Jpn. J. Cancer Res. 82: 1421-1427

Ng, I. O. L., Srivastava, G., Chung, L. P., Tsang, S. W. Y. and Ng, M. M. T. (1994) Overexpression and point mutations of p53 tumor suppressor gene in hepatocellular carcinomas in Hong Kong Chinese people. Cancer 74: 30-37

Nigro, J. M., Baker, S. J., Preisinger, A. C., Jessup, J. M., Hostetter, R., Cleary, K. Bigner, S. H., Davidson, N., Baylin, S., Devilee, P., Glover, T., Collins, F. S., Weston, 
A., Modali, R., Harris, C. C. and Vogelstein, B. (1989) Mutations in the $p 53$ gene occur in diverse human tumour types. Nature 342: 705-708

Nishida, N., Fukuda, Y., Kokuryu, H., Toguchida, J., Yandell, D. W., Ikenega, M., Imura, H. and Ishizaki, K. (1993) Role and mutational heterogeneity of the $p 53$ gene in hepatocellular carcinoma. Cancer Res. 53: 368-372

Nose, H., Imazeki, F., Ohto, M. and Omata, M. (1993) p53 gene mutations and 17p allelic deletions in hepatocellular carcinoma from Japan. Cancer 72: 355-360

Oda, T., Tsuda, H., Scarpa, A., Sakamoto, M. and Hirohashi, S. (1992) Mutation pattern of the p53 gene as a diagnostic marker for multiple hepatocellular carcinoma. Cancer Res. 52: 3674-3678

Ozturk, M. Bressac, B., Puisieux, A., Kew, M., Volkmann, M., Bozcall, S., Mura, J. B., de la Monte, S., Blum, H., Wands, J., Takahashi, H., von Weizacker, F., Galun, E., Kar, S., Carr, B. I., Schroder, C. H., Erken, E., Varinli, S., Rustgi, V.,Prat, J., Toda, G., Koch, H. K., Liang, X. H., Tang, Z.-Y., Shouval, D., Lee, H.-S., Vyas, G. N. and Sarosi, I. (1991) p53 mutation in hepatocellular carcinoma after aflatoxin exposure. Lancet 338: $1356-1359$

Scorsone, K. A., Zhou, Y.-Z., Butel, J. S. and Slagle, B. L. (1992) p53 mutations cluster at codon 249 in hepatitis B virus-positive hepatocellular carcinomas from China. Cancer Res. 52: 1635-1638

Sheu, J.-C., Huang, G.-T., Lee, P.-H., Chung, J.-C., Chou, H.-C., Lai, M.-Y., Wang, J.T., Lee, H.-S., Shih, L.-N., Yang, P.-M., Wang, T.-H. and Chen, D.-S. (1992) Mutation of p53 gene in hepatocellular carcinoma in Taiwan. Cancer Res. 52: 6098-6100

Teramoto, T., Satonaka, K., Kitazawa, S., Fujimori, T., Hayashi, K. and Maeda, S. (1994) p53 gene abnormalities are closely related to hepatoviral infections and occur at a late stage of hepatocarcino-genesis. Cancer Res. 54: 231-235

Unsal, H., Yakicier, C., Marais, C., Kew, M., Volkmann, M., Zentgraf, H., Isselbacher, K. J. and Ozturk, M. (1994) Genetic heterogeneity of hepatocellular carcinoma. Proc. Natl. Acad. Sci. U.S.A. 91: 822-826 